\title{
Thermal influence of saliva secretion ex vivo in the mouse submandibular gland
}

\author{
Taro Mukaibo, Tetsuji Nakamoto, Yusuke Kondo, Manami Kidokoro, Atsushi Imamura, \\ Chihiro Masaki, Ryuji Hosokawa
}

Department of Oral Reconstruction and Rehabilitation, Kyushu Dental University, Kitakyushu, Japan

Email: "hosokawa@kyu-dent.ac.jp

Received 28 January 2013; revised 2 March 2013; accepted 12 March 2013

\begin{abstract}
The physiological and pharmacological responses of an ex vivo mouse submandibular gland were used to study fluid secretion and cell signaling in response to muscarinic stimulation at increasing temperatures. Saliva production at $37^{\circ} \mathrm{C}$ was 5.5 -fold that at $25^{\circ} \mathrm{C}$ with pilocarpine stimulation and 9.8 -fold that at $25^{\circ} \mathrm{C}$ with cevimeline stimulation. Both of these muscarinic agonists are used clinically. With the experimental agonist carbachol (CCh), saliva secretion was increased with an increase in temperature, but the $\mathrm{CCh}$ concentration producing the peak flow was the same in both dose-response curves, suggesting that the muscarinic receptor itself is not responsible for the temperature dependence. Purinergic agonists also induced temperature-dependent saliva production $e x$ vivo. The calcium ionophore A23187 failed to have a significant effect on saliva production. The CCh-induced increase in intracellular $\mathrm{Ca}^{2+}$ also upregulated the initial increase and sustained the plateau phase of saliva flow. Thus, muscarinic receptor stimulation of saliva production is temperature sensitive due to an increase in intracellular $\mathrm{Ca}^{2+}$.
\end{abstract}

Keywords: Submandibular Gland; Fluid Secretion; Cevimeline; Pilocarpine; Thermal Influence

\section{INTRODUCTION}

The salivary glands are a group of glands that include the parotid, submandibular, sublingual, and minor salivary glands. These glands secrete water, ions, and digestive enzymes into the oral cavity and function in disinfection, digestion, and taste. Salivary gland hypofunction can result in xerostomia, or dry mouth, which can greatly affect the quality of life. The detailed mechanism of this process is poorly understood, and although complex therapies are often used, there is no definitive treatment.

"Corresponding author.
More than $95 \%$ of saliva is water, which is produced by the coordinated functions of channels and transporters distributed in the basolateral and apical membranes of salivary acinar and ductal cells [1,2]. Stimulation of muscarinic receptors M1-M4 triggers saliva secretion, and the M3 receptor plays a central role in this process [3]. Muscarinic agonists such as pilocarpine and cevimeline have been used clinically to activate saliva secretion in patients with Sjögren's syndrome and in patients suffering from side effects of irradiation for head and neck cancers $[4,5]$. A number of factors which influence saliva secretion such as blood flow, central nervous effect [6] and dose of agonists have been reported [7]. We focus on the temperature as a factor which influence the muscarinic-induced salivation and try to find out whether the salivary gland itself has temperature sensitivity. Increased temperature enhances muscarinic-stimulated inositol 1,4,5-trisphosphate production in the guinea pig cerebral cortex [8] and enhances the muscarinic response in endothelial cells [9]. Hyperthermia has been reported as an effective therapy for salivary gland hypofunction because the salivary glands are located just below the skin. Seasonal changes in temperature can also affect salivary flow, and the elevation of body temperature in rats was shown to increase saliva secretion [10]. Despite these studies, the muscarinic-induced responses of Salivary glands at different temperatures are poorly characterized. In this study, we used a mouse salivary gland perfusion technique to study fluid secretion and cell signaling in response to muscarinic stimulation at increasing temperatures.

\section{MATERIAL AND METHODS}

\subsection{Drugs}

Collagenase L was obtained from Nitta Gelatin (Osaka, Japan). Pilocarpine was purchased from Nacalai Tesque (Kyoto, Japan). Cevimeline was a gift from Nippon Kayaku (Tokyo, Japan). Fura-2 AM was obtained from Dojindo (Kumamoto, Japan). Sodium chloride, potassium 
chloride, sodium bicarbonate, magnesium chloride, calcium chloride dihydrate, D-(+)-glucose, HEPES, bovine serum albumin, carbachol, 3'-O-(4-benzoylbenzoyl) adenosine 5'-triphosphoric acid (BzATP), propranolol, atropine, A23187, and all other chemicals were purchased from Sigma Japan (Tokyo, Japan).

\subsection{Animals}

All experiments were approved by the Animal Use Committee of Kyushu Dental College. C57BL/6J mice, purchased from Kyushu Animal Laboratory, were acclimated to a 12-h light/dark cycle and were fed ad libitum. Experiments were performed in mice at $8-10$ weeks of age.

\subsection{Ex Vivo Mouse Submandibular Gland Analysis}

An ex vivo vascular perfusion technique was used to accurately control thermal conditions and eliminate neurological input for analysis of glandular fluid secretion. The surgical procedure has been previously described $[12,13]$. The submandibular glands were dissected, and the main artery was cannulated with a 31-gauge bluntend cannula and perfused at a flow rate of $1 \mathrm{ml} / \mathrm{min}$. The perfusion solution consisted of $120 \mathrm{mM} \mathrm{NaCl}, 4.3 \mathrm{mM}$

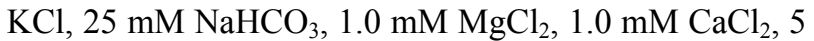
$\mathrm{mM}$ glucose, and $10 \mathrm{mM}$ HEPES equilibrated with $95 \%$ $\mathrm{O}_{2} / 5 \% \mathrm{CO}_{2}$ and stored at room temperature. A custommade water-jacket heating system was used to control the temperature of the solutions and glands. Fluid secretion was stimulated by the addition of a submaximal concentration of the muscarinic agonist carbachol (CCh, 0.3 $\mu \mathrm{M})$. The secreted saliva was collected in a pre-calibrated glass capillary tube.

\subsection{Intracellular $\mathrm{Ca}^{2+}$ Measurements}

Intracellular $\mathrm{Ca}^{2+}\left(\left[\mathrm{Ca}^{2+}\right]_{\mathrm{i}}\right)$ was measured as previously described $[13,14]$. The submandibular glands were removed from anesthetized mice, placed in physiological saline $(120 \mathrm{mM} \mathrm{NaCl}, 4.3 \mathrm{mM} \mathrm{KCl}, 25 \mathrm{mM} \mathrm{NaHCO}$, $1.0 \mathrm{mM} \mathrm{MgCl}_{2}, 1.0 \mathrm{mM} \mathrm{CaCl}_{2}, 5 \mathrm{mM}$ glucose, and 10 $\mathrm{mM}$ HEPES supplemented with $1 \mathrm{mg} / \mathrm{ml}$ bovine serum albumin), minced approximately 100 times with fine scissors, and digested with $520 \mathrm{U} / \mathrm{ml}$ collagenase L for 20 min with continuous shaking. Dissociated cells were incubated with $1 \mu \mathrm{M}$ Fura-2 AM to measure $\left[\mathrm{Ca}^{2+}\right]_{i}$. A custom-made water-jacket heating system was used to control the temperature of the cells and perfusion solutions. Fluorescence was detected under a microscope equipped with a fluorescence analysis system (Argus/ Aquacosmos; Hamamatsu Photonics, Hamamatsu, Japan), with excitation at 340 and $380 \mathrm{~nm}$ and emission at $510 \mathrm{~nm}$. The $\left[\mathrm{Ca}^{2+}\right]_{\mathrm{i}}$ was calculated as the ratio of the emissions following excitation at 380 and $340 \mathrm{~nm}$.

\subsection{Statistical Analysis}

The data are shown as means \pm standard error (S.E.). Student's t-test was used to compare group means. To detect statistically significant differences in multiple comparisons, one-way analysis of variance (ANOVA) followed by Tukey's post-hoc test was performed using SPSS v.14.0J (SPSS, Chicago, IL). Results were deemed statistically significant at $\mathrm{P} \leq 0.05$.

\section{RESULTS}

\subsection{Fluid Secretion in Response to Clinically and Experimentally Used Muscarinic Agonists}

We compared fluid secretion in response to the clinically used muscarinic agonists pilocarpine and cevimeline, and the experimentally used agonist $\mathrm{CCh}$. The flow rate data are summarized in Figures 1(a), (c) and (e) (Figure 1). At all temperatures tested, all three muscarinic agonists induced fluid secretion. At $25^{\circ} \mathrm{C}$ and $30^{\circ} \mathrm{C}$, secretion was high for the first $30 \mathrm{~s}$, decreased slightly over the next 30 $\mathrm{s}$, and then remained constant. At $37^{\circ} \mathrm{C}$ and $42^{\circ} \mathrm{C}$, there was no decrease at $30-60 \mathrm{~s}$.

The total secretion over $10 \mathrm{~min}$ is shown in Figures 1(b), (d) and (f). Initially, $10 \mu \mathrm{M}$ pilocarpine induced $175.1 \pm 17.3 \mu \mathrm{L}$ of saliva ex vivo during the 10 -min stimulation at $37^{\circ} \mathrm{C}$; this was 5.5 -fold the amount of saliva produced at $25^{\circ} \mathrm{C}$. The increase between $37^{\circ} \mathrm{C}$ and $42^{\circ} \mathrm{C}$ was not significant (Figure 1(b)). In contrast, 30 $\mu \mathrm{M}$ cevimeline produced $118.0 \pm 4.3 \mu \mathrm{L}$ of saliva at $37^{\circ} \mathrm{C}$, which was 9.8 -fold the amount of saliva produced at $25^{\circ} \mathrm{C}$, and all cevimeline-induced increases were significant at all temperatures tested (Figure 1(d)). Treatment with $0.3 \mu \mathrm{M} \mathrm{CCh}$ induced the production of $148.4 \pm 3.2$ $\mu \mathrm{L}$ of saliva ex vivo during the 10 -min stimulation at $37^{\circ} \mathrm{C}$, which was 2.3 -fold the amount of saliva produced at $25^{\circ} \mathrm{C}$; the increase between $37^{\circ} \mathrm{C}$ and $42^{\circ} \mathrm{C}$ was not significant (Figure 1(f)).

\subsection{The Dose Response to Carbachol at $25^{\circ} \mathrm{C}$ and $37^{\circ} \mathrm{C}$}

Only small amounts of saliva were collected in response to lower concentrations $(\sim 3 \mu \mathrm{M})$ of pilocarpine and cevimeline at $25^{\circ} \mathrm{C}$, leading us to investigate the response to a series of CCh concentrations at $25^{\circ} \mathrm{C}$ and $37^{\circ} \mathrm{C}$.

Although the dose-response curve was shifted upward at the higher temperature, the $\mathrm{CCh}$ concentration producing the peak flow was the same for both curves (Figure 2). These results suggest that muscarinic receptors are not responsible for the temperature dependence of the increased secretion ex vivo. We analyzed the ionic composition of the collected saliva and found no significant 


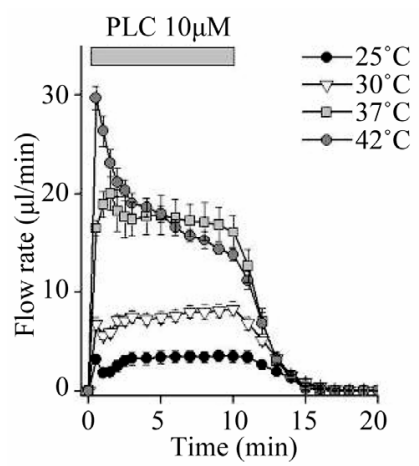

(a)

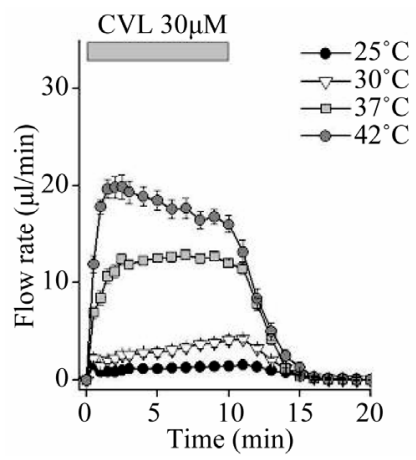

(c)

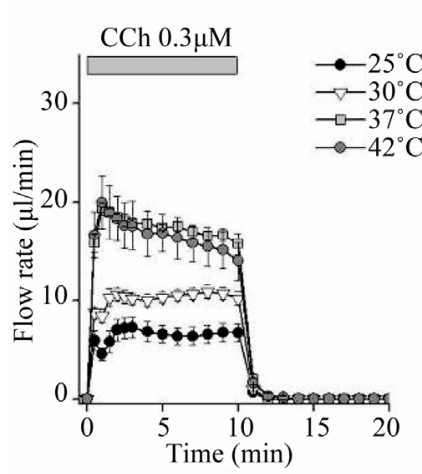

(e)

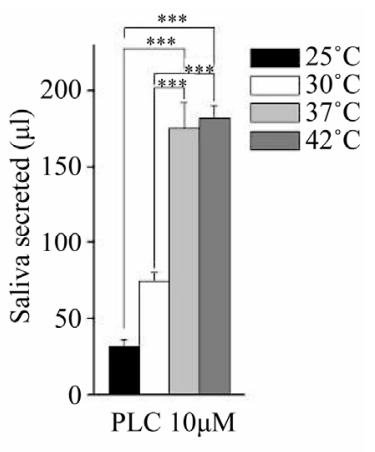

(b)

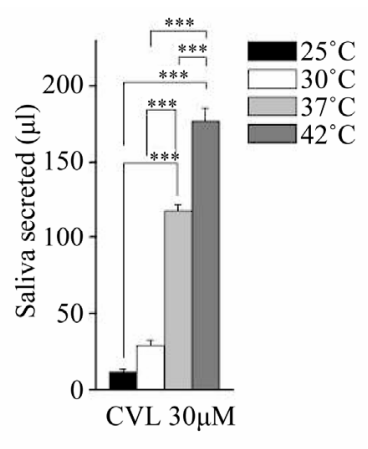

(d)

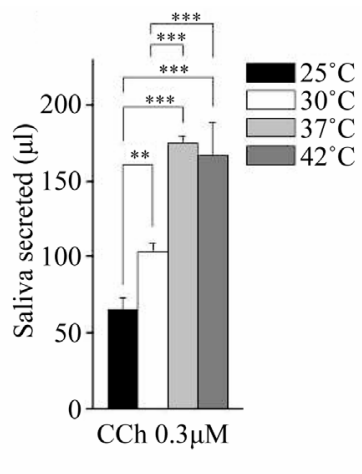

(f)
Figure 1. Ex vivo mouse submandibular gland secretion in response to receptor-mediated $\mathrm{Ca}^{2+}$ mobilizing agents at 25,30, 37 , and $42^{\circ} \mathrm{C}$. (a), (c) and (e): The salivary flow rate in response to $10 \mu \mathrm{m}$ pilocarpine (PLC: $25^{\circ} \mathrm{C}, \mathrm{n}=6 ; 30^{\circ} \mathrm{C}, \mathrm{n}=11 ; 37^{\circ} \mathrm{C}, \mathrm{n}$ $\left.=7 ; 42^{\circ} \mathrm{C}, \mathrm{n}=7\right), 30 \mu \mathrm{m}$ cevimeline $\left(\mathrm{CVL} ; 25^{\circ} \mathrm{C}, \mathrm{n}=6 ; 30^{\circ} \mathrm{C}\right.$, $\left.\mathrm{n}=10 ; 37^{\circ} \mathrm{C}, \mathrm{n}=11 ; 42^{\circ} \mathrm{C}, \mathrm{n}=10\right)$, and $0.3 \mu \mathrm{M}$ carbachol (CCh: $25^{\circ} \mathrm{C}, \mathrm{n}=8 ; 30^{\circ} \mathrm{C}, \mathrm{n}=12 ; 37^{\circ} \mathrm{C}, \mathrm{n}=6 ; 42^{\circ} \mathrm{C}, \mathrm{n}=8$ ). The submandibular glands were cannulated and perfused with physiological saline for $10 \mathrm{~min}$ at each temperature before being stimulated with agonist for $10 \mathrm{~min}$. (b), (d) and (f): Bar graphs depicted total secretion over $10 \mathrm{~min} .{ }^{*} \mathrm{P}<0.05,{ }^{* *} \mathrm{P}<0.01,{ }^{* * *} \mathrm{P}$ $<0.001$ by ANOVA and Tukey's post-hoc test.

changes among the tested conditions.

\subsection{Fluid Secretion in Response to P2X7 Agonist and $\mathrm{Ca}^{2+}$ Ionophore}

To identify the effect of the $\mathrm{P} 2 \mathrm{X} 7$ receptor on the tem-

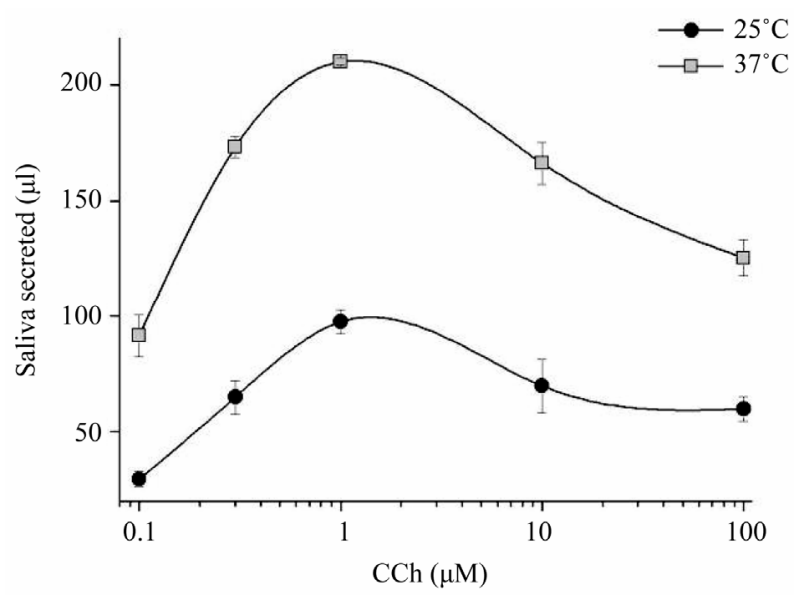

Figure 2. Dose-response curve for stimulation with carbachol. Salivary glands were perfused with carbachol (CCh) at $0.1,0.3$, 1,10 , and $100 \mu \mathrm{M}$, at $25^{\circ} \mathrm{C}$ and $37^{\circ} \mathrm{C}$. The dose-response curve shifted upward between $25^{\circ} \mathrm{C}$ and $37^{\circ} \mathrm{C}$, but the peak response remained at $1 \mu \mathrm{M}(\mathrm{n}=3$ or more at each concentration).

perature-dependent increases, we tested the effect of the P2X7 agonist 3'-O-(4-benzoylbenzoyl) adenosine 5'-triphosphoric acid (BzATP) at $0.5 \mathrm{mM}$ in the presence of both the muscarinic antagonist atropine $(0.5 \mu \mathrm{M})$ and the $\beta$-antagonist propranolol $(20 \mu \mathrm{M})$. The initial peak flow rate resulted in a 1.5 -fold increase between $25^{\circ} \mathrm{C}$ and $37^{\circ} \mathrm{C}$, but the difference in the total amount of saliva secretion was not statistically significant (Figure 3). We also tested A23187 $(1 \mu \mathrm{M})$, a calcium ionophore, to bypass muscarinic-dependent signaling. A23187 produced almost identical amounts of saliva secretion at $25^{\circ} \mathrm{C}$ and $37^{\circ} \mathrm{C}$ (Figure 4), indicating that $\mathrm{Ca}^{2+}$ influx mechanisms are not involved in temperature-dependent fluid secretion ex vivo.

\subsection{Intracellular $\mathrm{Ca}^{2+}$ Response during Carbachol Stimulation}

The measurements of $\left[\mathrm{Ca}^{2+}\right]_{\mathrm{i}}$ during carbachol stimulation revealed significant differences in the fluorescence ratios at the peak and the plateau level between $25^{\circ} \mathrm{C}$ and $37^{\circ} \mathrm{C}$ (Figure 5). This result, combined with the results in Figure 1(c), suggests that the muscarinic-stimulated increase in saliva secretion may be attributable to an intracellular $\mathrm{Ca}^{2+}$ handling mechanism.

\section{DISCUSSION}

Our findings suggest that muscarinic or purinergic receptor activation is temperature sensitive (Figures $\mathbf{1}$ and 3) and that the extent of the temperature-dependent increase differs among muscarinic agonists. Compared with $\mathrm{CCh}$, pilocarpine and cevimeline stimulated weak responses at $25^{\circ} \mathrm{C}$, but were more potent at higher temperatures; in particular, cevimeline was more potent at 


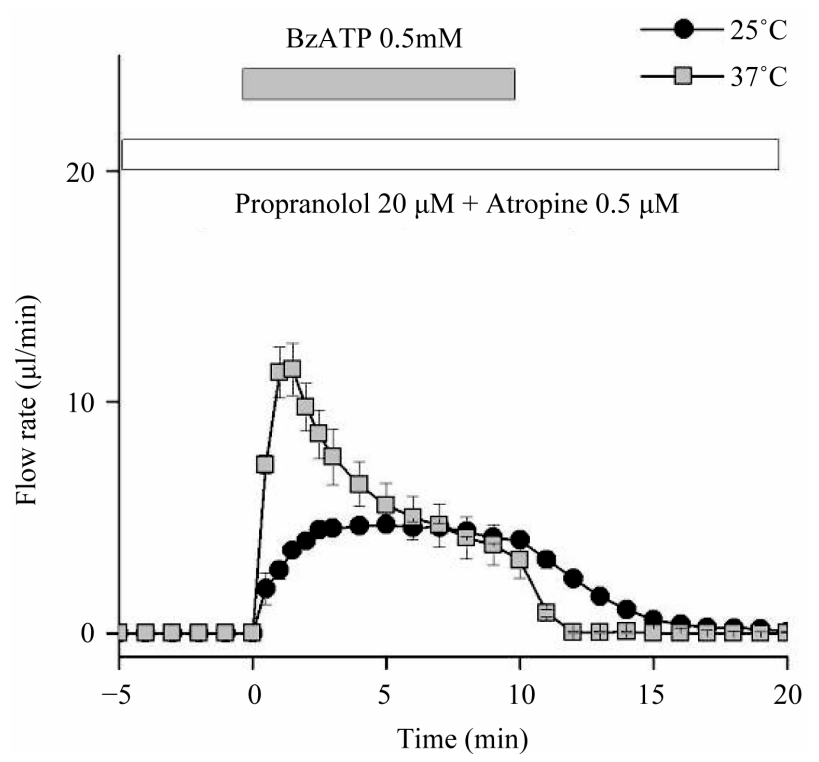

Figure 3. The salivary flow rate in response to the $\mathrm{P} 2 \mathrm{X} 7$ agonist BzATP. Ex vivo flow rate in response to the $\mathrm{P} 2 \mathrm{X} 7$ agonist BzATP in the presence of the muscarinic inhibitor atropine $(0.5 \mu \mathrm{M})$ and the $\beta$-blocker propranolol $(20 \mu \mathrm{M})$, at both $25^{\circ} \mathrm{C}$ and $37^{\circ} \mathrm{C}$. The initial peak flow rate resulted in a 1.5 -fold increase, but the total amount of saliva secretion did not differ significantly between the two temperatures $(n=6$ for both conditions).

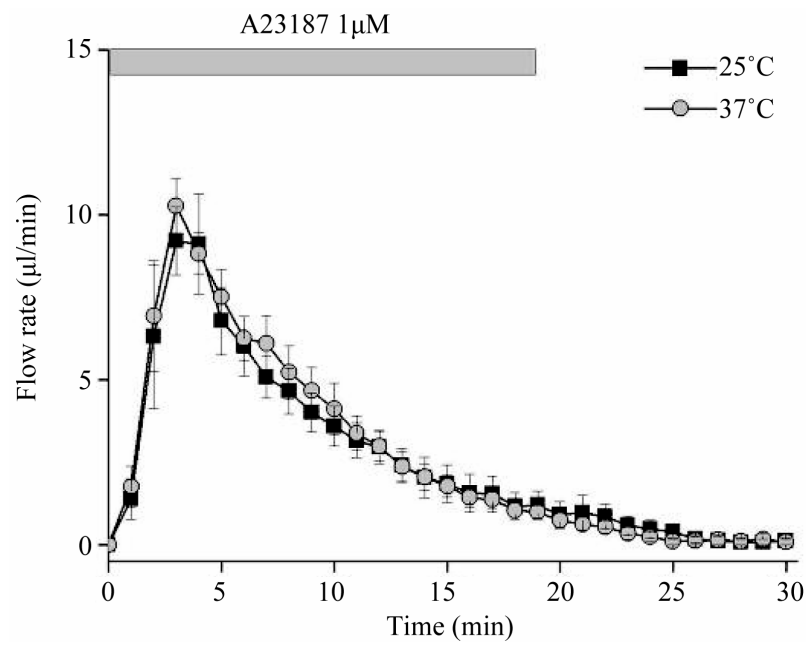

Figure 4. Saliva secretion induced ex vivo by the $\mathrm{Ca}^{2+}$ ionophore A23187. Submandibular glands were perfused with physiological saline and stimulated with $1 \mu \mathrm{M}$ A23187, at both $25^{\circ} \mathrm{C}$ and $37^{\circ} \mathrm{C}$. There was no significant difference in secretion between the two temperatures ( $\mathrm{n}=6$ for both conditions).

$42^{\circ} \mathrm{C}$ than at $37^{\circ} \mathrm{C}$. Pilocarpine and cevimeline are used clinically, but treatment is not always successful. The present results suggest that measuring the temperature around the salivary glands may be useful prior to administering pilocarpine and/or cevimeline to patients and that thermal therapy should be considered before increasing the dose.
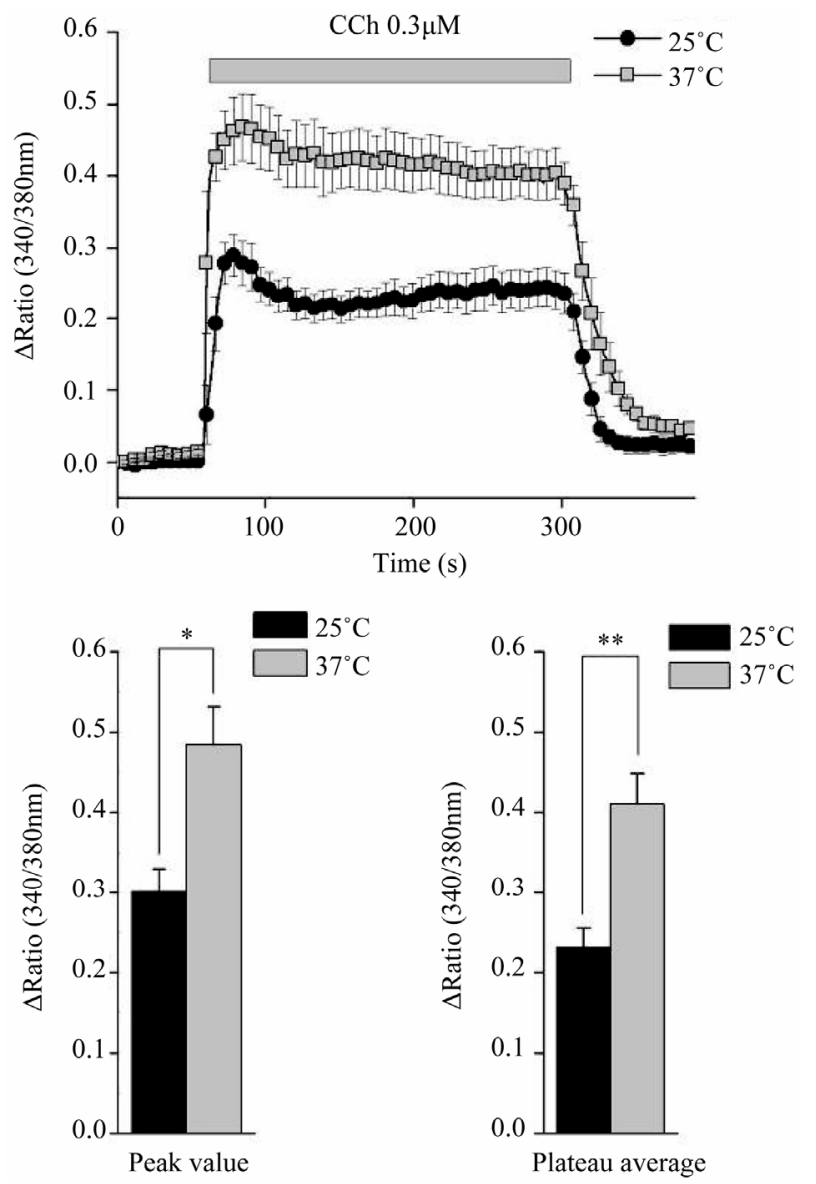

Figure 5. Carbachol-induced intracellular $\mathrm{Ca}^{2+}$ signaling. The ratio of Fura- $2 \mathrm{AM}$ in response to $0.3 \mu \mathrm{M}$ carbachol $(\mathrm{CCh})$ at $25^{\circ} \mathrm{C}$ and $37^{\circ} \mathrm{C}$, measured using clumpy cell preparations. Cells were equilibrated at each temperature and then stimulated for the time shown (upper panel). The peak ratio value (lower left) and plateau average ratio value between 60 and $240 \mathrm{~s}$ (lower right) differed significantly between the two temperatures $(\mathrm{n}=$ 5 for both measurements). ${ }^{*} \mathrm{P}<0.05$ and ${ }^{* *} \mathrm{P}<0.01$, Student's t-test.

The present results indicate that $\mathrm{Ca}^{2+}$ influx mechanisms (Figure 4) and $\mathrm{Ca}^{2+}$ depletion signals [data not shown) are not involved in temperature-dependent saliva secretion ex vivo. The absence of a shift in the response to $0.3 \mu \mathrm{M}$ CCh between the two temperatures (Figure 2) suggests that the muscarinic receptor itself is also not involved, but that downstream signaling is responsible.

Unexpectedly, a temperature-dependent increase in saliva flow occurred with BzATP (Figure 3). Salivary cells express $\mathrm{P} 2 \mathrm{X} 4, \mathrm{P} 2 \mathrm{X} 7, \mathrm{P} 2 \mathrm{Y} 1$, and $\mathrm{P} 2 \mathrm{Y} 2$ purinergic receptors $[13,14]$, and $\mathrm{P} 2 \mathrm{X} 7$ is primarily involved in purinergic receptor-induced fluid secretion [15]. P2X7 is an ionotropic receptor, and we expected to see results similar to those with the $\mathrm{Ca}^{2+}$ ionophore A23187 (Figure 4). Since we used a relatively high concentration of BzATP, $G$ protein-coupled signaling via $\mathrm{P} 2 \mathrm{Y}$ receptor activation may be involved in this temperature response. 
Our results correlate with previous findings in mouse endothelial cells, which have a temperature-sensitive response to muscarinic stimulation [9]. The Kd of Fura-2 AM differs between the two temperatures used in the present study, but the relative fluorescence emissions with 340- and 380-nm excitation were essentially identical at the two temperatures. In agreement with previous findings, the fluorescence ratio, which indicates $\left[\mathrm{Ca}^{2+}\right]_{i}$, in response to $0.3 \mu \mathrm{M} \mathrm{CCh}$ differed between $25^{\circ} \mathrm{C}$ and $37^{\circ} \mathrm{C}$ (Figure 5), and the basal ratio before stimulation was slightly higher at $37^{\circ} \mathrm{C}$. The binding of $\mathrm{CCh}$ to $\mathrm{G}$ protein-coupled muscarinic receptors activates phospholipase $\mathrm{C}$ to generate 1,4,5-inositol triphosphate, which could induce the initial increase in $\left[\mathrm{Ca}^{2+}\right]_{\mathrm{i}}$ and the consequent initial peak flow of saliva. Therefore, $\mathrm{G}$ proteincoupled $\mathrm{Ca}^{2+}$ efflux from the endoplasmic reticulum appears to be responsible for the increased salivary gland secretion at $37^{\circ} \mathrm{C}$ under $\mathrm{Ca}^{2+}$-stimulated conditions. Additionally, $\mathrm{Ca}^{2+}$ influx mechanisms were not sensitive to temperature (Figure 4), and a store-depletion signal had no effect (data not shown). We examined another $\mathrm{Ca}^{2+}$ pathway via the thermo-sensitive and osmo-sensitive cation channel TRPV4 [16-22]. We used the putative TRPV4 activator $4 \alpha$ PDD $[17,18]$ and the TRPV4 inhibitor RN1734 [19], but failed to see any change in fluid secretion under several different conditions (data not shown).

Our results clearly show the importance of temperature control in fluid secretion induced by intracellular signaling. Neither $\mathrm{Ca}^{2+}$ influx mechanisms nor storedepletion signaling are involved. Since rodents spread their saliva on the scrotum and fur in order to cool themselves by evaporation of the saliva at high temperature conditions, even though further study is needed to clarify whether the same result is observed in human, these results suggest that thermal control may have clinical relevance in treating dry mouth such as regional hyperthermia to human salivary glands.

\section{ACKNOWLEDGEMENTS}

We thank Nippon Kayaku for kindly providing cevimeline.

\section{REFERENCES}

[1] Melvin, J.E., Yule, D., Shuttleworth, T., et al. (2005) Regulation of fluid and electrolyte secretion in salivary gland acinar cells. Annual Review of Physiology, 67, 445469. doi:10.1146/annurev.physiol.67.041703.084745

[2] Roussa, E. (2011) Channels and transporters in salivary glands. Cell and Tissue Research, 343, 263-287. doi:10.1007/s00441-010-1089-y

[3] Nakamura, T., Matsui, M., Uchida, K., et al. (2004) M(3) muscarinic acetylcholine receptor plays a critical role in parasympathetic control of salivation in mice. Journal of
Physiology, 558, 561-575. doi:10.1113/jphysiol.2004.064626

[4] Berk, L. (2008) Systemic pilocarpine for treatment of xerostomia. Expert Opinion on Drug Metabolism \& Toxicology, 4, 1333-1340. doi:10.1517/17425255.4.10.1333

[5] Braga, M.A., Tarzia, O., Bergamaschi, C.C., et al. (2009) Comparison of the effects of pilocarpine and cevimeline on salivary flow. International Journal of Dental Hygiene, 7, 126-130. doi:10.1111/j.1601-5037.2008.00326.x

[6] Lung, M.A. (1990) Variations in blood flow on mandibular glandular secretion to autonomic nervous stimulations in anaesthetized dogs. Journal of Physiology, 431, 479-493.

[7] Iwabuchi, Y., Aoki, C. and Masuhara, T. (1988) A comparative study of the effects of four choline esters on the secretion of fluid and glycoprotein from rat submandibular glands. Japanese Journal of Pharmacology, 48, 175184. doi:10.1254/jip.48.175

[8] Carswell, H., Galione, A.G. and Young, J.M. (1987) Differential effect of temperature on histamine- and carbachol-stimulated inositol phospholipid breakdown in slices of guinea-pig cerebral cortex. British Journal Pharmacology, 90, 175-182. doi:10.1111/j.1476-5381.1987.tb16838.x

[9] Socha, M.J., Hakim, C.H., Jackson, W.F., et al. (2011) Temperature effects on morphological integrity and $\mathrm{Ca}^{2+}$ signaling in freshly isolated murine feed artery endothelial cell tubes. American Journal of Physiology Heart Circulatory Physiology, 301, H773-H783. doi:10.1152/ajpheart.00214.2011

[10] Kanosue K., Nakayama, T., Tanaka, H., et al. (1990) Modes of action of local hypothalamic and skin thermal stimulation on salivary secretion in rats. Journal of Physiology, 424, 459-471.

[11] Nakayama, T., Kanosue, K., Tanaka, H., et al. (1986) Thermally induced salivary secretion in anesthetized rats. Pflugers Archives European Journal of Physiology, 406, 351-355. doi:10.1007/BF00590935

[12] Nakamoto, T., Romanenko, V.G., Takahashi A., et al., (2008) Apical maxi-K (KCa1.1) channels mediate $\mathrm{K}^{+}$secretion by the mouse submandibular exocrine gland. American Journal of Physiology Cellular Physiology, 294, C810-C819. doi:10.1152/ajpcell.00511.2007

[13] Romanenko, V.G., Nakamoto, T., Srivastava, A., et al. (2007) Regulation of membrane potential and fluid secretion by $\mathrm{Ca}^{2+}$-activated $\mathrm{K}^{+}$channels in mouse submandibular glands. Journal of Physiology, 581, 801-817. doi:10.1113/jphysiol.2006.127498

[14] Kondo, Y., Nakamoto, T., Mukaibo, T., et al. (2011) Cevimeline-induced monophasic salivation from the mouse submandibular gland: Decreased $\mathrm{Na}^{+}$content in saliva results from specific and early activation of $\mathrm{Na}^{+} / \mathrm{H}^{+}$exchange. Journal of Pharmacology and Experimental Therapeutics, 337, 267-274. doi:10.1124/jpet.110.174946

[15] Nakamoto, T., Hirono, C., Sugita, M., et al. (2002) Forskolin-induced clearance of the fluorescent dye sulforhodamine from rat parotid intralobular duct lumen: Visualization of the secretory function under a confocal laser scaning microscope. Journal of Membrane Biology, 190, 
189-196. doi:10.1007/s00232-002-1036-2

[16] Turner, J.T., Landon, L.A., Gibbons, S.J., et al. (1999) Salivary gland P2 nucleotide receptors. Critical Reviews in Oral Biology \& Medicine, 10, 210-224. doi:10.1177/10454411990100020701

[17] Turner, J.T., Weisman, G.A., Landon, L.A., et al. (1998) Salivary gland nucleotide receptors: Evidence for functional expression of both P2X and P2Y subtypes. European Journal of Morphology, 36, 170-175.

[18] Nakamoto, T., Brown, D.A., Catalan, M.A., et al. (2009) Purinergic P2X7 receptors mediate ATP-induced saliva secretion by the mouse submandibular gland. Journal of Biological Chemistry, 284, 4815-4822. doi:10.1074/jbc.M808597200

[19] Montell, C. (2005) The TRP superfamily of cation channels. Science's STKE: Signal Transduction Knowledge
Environment, 2005, 3.

[20] Nilius, B., Vriens, J., Prenen, J., et al. (2004) TRPV4 calcium entry channel: A paradigm for gating diversity. American Journal of Physiology Cellular Physiology, 286, C195-C205. doi:10.1152/ajpcell.00365.2003

[21] Vriens, J., Janssens, A., Prenen, J., et al. (2004) TRPV channels and modulation by hepatocyte growth factor/ scatter factor in human hepatoblastoma (HepG2) cells. Cellular Calcium, 36, 19-28. doi:10.1016/j.ceca.2003.11.006

[22] Vincent, F., Acevedo, A., Nguyen, M.T., et al. (2009) Identification and characterization of novel TRPV4 modulators. Biochemical and Biophysical Research Communications, 389, 490-494.

doi:10.1016/j.bbrc.2009.09.007 